\title{
STUDIES ON SOME PHYSICAL PROPERTIES OF EGYPTIAN AND IRAQIAN HONEY.
}

Fathy, H. M.; S. S. Awadalla; L. A. El-Batran and M. H. A. Al-Mashhadani

Plant protection Department, Faculty of Agriculture, Mansoura University.

\begin{abstract}
Eighteen honey samples were collected from Egyptian and Iraqian to evaluate some physical properties: Moisture(\%), Total soluble solids(TSS), Electrical conductivity(EC), Viscosity and Specific gravity. The final results indicated that it was not found significant difference between Egyptian and Iraqian honeys in relation to moisture percentages. It not found significant differences between Egyptian and Iraqian honeys in relation to soluble solids (TSS\%). The obtained results cleared that low significant differences between Egyptian and Iraqian honeys in relation to Electrical conductivity (EC). The results indicated that low significant differences between Egyptian and Iraqian honeys in relation to viscosity. In relation to specific gravity in both Egyptian and Iraqian honey samples, it not found significant differences between Egyptian honey (clover, citrus and cotton) and also between Iraqian honeys in all samples.
\end{abstract}

\section{INTRODUCTION}

Honey can be said the miracle food, because of its nutritional and health benefits bestowed to human beings since centuries. Honey is the natural sweet substance produced by certain species of bees, from the nectar of plant, from secretion of living part of plant, which honey bee collected transformed and compbined with specific substances of their own store and leave in honey comb to ripen and nature. (Codex Alimentation 1998). The use of honey as a therapeutic compound has been explored by the medical profession in more recent times. Honey comes in the first order of these products, since it has many benefits in foods and medicine (Serrano et al, 2007). Honey is the most important primary product of beekeeping both from quantitative and an economic point of view (Crane 1990). Honey has several important properties in addition to its composition and colour. It is composed mainly of carbohydrates, lesser amounts of water and a wide range of minor components (white, 1980 and El-Metwally, 2015). The aim of this study evaluate some physical and chemical properties of Egyptian and Iraqian honeys according to Egyptian honey standard (2005) and Iraqian honey standard(1984). 


\section{MATERIALS AND METHODS}

The present study was carried out in Economic Entomology Department Faculty of Agriculture, Mansoura University. Some physical properties of Egyptian and Iraqian honeys were evaluated in Chemical analysis . lap of honey bee products, Bee keeping Research Department , plant Protection Research Institute, Giza, Eighteen honey samples were collected from Egypt and Iraq.

All honey samples obtained from beekeepers during years 2014, were labeled by different serial numbers and accompanied with its type date of harvesting and regions.

Honey test methods:

According to Codex Alimentarius commissions (2001), Egyptian stand. NO: 355, (2005), Iraqian stand.(1984)., and official methods of analysis of Associaticen of official chemists (A.O.A.C.1980) edited by sinday Williams, honey test methods were carried out.

Determination of physical properties of Egyptian and Iraqian honey samples:

- Water content (Moisture):

Determination of moisture content of honey was carried out by measurement its refractive index value (abbe refractometer at $20{ }^{\circ} \mathrm{C}$ ) from 100\%(A.O.A.C 1995).

- Electrical conductivity (E.C):

Based on the method of Vorwhol (1964), using model EN50081-1 at room temperature, weigh tow $\mathrm{gm}$ of honey dissolved in ten $\mathrm{ml}$ of distilled water. The results are expressed as ppm.

\section{- Total soluble solids (T.S.S)of honey:}

The coarse materials within honey sample should be removed before determination the (TSS) therefore; the honey sample was stirred at room temperature and pass through a( $0.5 \mathrm{~mm})$ sieve, The granulated honey samples were liquid in water bath at $\left(40^{\circ} \mathrm{C}\right)$, and then the flask which contained honey was cooled and stirred at room temperature, (A.O.A.C., 1980).

Equipment: Abbe refractometer was used and expressing the (TSS) in honey in percentage.

- Viscosity:

The capillary viscometric measurements were performed using an Ostwald viscometer. The viscometer was initially calibrated using doubled distilled water and $20 \%$ sucrose solution calculated amount of distilled water was added to the fresh honey sample to raise percentage water content to $25-50$ range. The viscosities of the samples were measured for each of the samples at $15,25,35,45$ and $60^{\circ} \mathrm{C}$. 
- Specific gravity:

The specific gravity (SG) of the samples obtamied as the ratio of the weight of sample to that of equal volume of water.

\section{Where:}

$$
S G=\frac{\text { Wsb - Wb }}{\text { Wwb - Wb }}
$$

$\mathrm{Wb}=$ weight of the pycnometer

$W s b=$ weight of sample + pycnometer

$\mathrm{Wwb}=$ weight of water + pycnometer

\section{RESULTS AND DISCUSSION}

\section{Some physical properties of Egyptian and Iraqian honey samples:}

\section{Moisture content:.}

The Egyptian standard (2005) decreased the maximum level to be $20 \%$ for the nectar honey, while the Iraqian standard (1984) had a maximum level $21 \%$.

Data in Tables 1, 2, 3 and 4 and Figures 1 and 2 illustrated that the honey may be divided into three groups : the first groups include eight samples characterized by its distinctive low moisture content $18 \%$ or less (from $18 \%$ to $16 \%$ ), which will not fermented in a year according to EL-Ansary (2007).

These samples were A2,(clover honey 18\%) from Egypt (Giza) and seven samples from Iraq (D1, D2, D3, D4, D5, D6 and D7). The pervious sample have water content values of $16.5,16.5,17,17,16,18$ and $17.5 \%$, respectively.

The second group includes eight samples accepted from Egyptian and Iraqian standard. These samples have relativity high moisture content ranged between 18.5 to $20 \%$ A1, A4, B1, B2, B3 and C1 from Egypt were 18.5, 19 , $19,20,19.5$ and $19 \%$, respectively. and D8 and D9 from Iraq. Were equal $(19 \%)$. The third group includes only two samples from Egypt (A3) refused by Egypt standard and (C2) refused by Egyptian and Iraqian standard.

The highest moisture percent was recorded $21.5 \%$ from Egyptian honey (cotton, C2), while the lowest percent of moisture was $16 \%$ from Iraqian honey (citrus, D5).

Statistical analysis of moisture content data for the honey samples are summarized in table (1, 2, 3 and 4), it was found insignificant differences between clover and citrus in Egyptian honey, while found significant differences between cotton and both citrus and clover.

In Iraqian honeys, it was insignificant differences between D1, D2, D3, D4, D5, D6 and D7, while found significant differences between D8 or D9 and other types.

Generally, it is clear that only three samples refused and fifteen samples were accepted from Egyptian and Iraqian honey standard (Tables 1, 2, 3 and 4), and the final results indicated that it was not found significant difference between Egyptian and Iraqian honeys in relation to moisture percentages. 
Fathy, H.M. et al.

Table 1: Some physical properties of Egyptian honeys.

\begin{tabular}{|c|c|c|c|c|c|c|}
\hline Honey type & Samples & $\begin{array}{c}\text { Moisture } \\
(\%)\end{array}$ & $\begin{array}{l}\text { EC * } \\
\text { ppm }\end{array}$ & $\begin{array}{l}\text { TSS } \\
(\%)^{*}\end{array}$ & \begin{tabular}{c|}
$V^{*}$ \\
(poise)
\end{tabular} & S.G * \\
\hline Clover & $\begin{array}{l}\text { A1 } \\
\text { A2 } \\
\text { A3 } \\
\text { A4 }\end{array}$ & $\begin{array}{l}18.50 \\
18.00 \\
21.00 \\
19.00\end{array}$ & $\begin{array}{l}0.019 \\
0.008 \\
0.011 \\
0.010\end{array}$ & $\begin{array}{l}81.50 \\
82.00 \\
79.00 \\
81.00\end{array}$ & \begin{tabular}{|l|}
48.10 \\
69.00 \\
13.60 \\
48.10 \\
\end{tabular} & $\begin{array}{l}1.41 \\
1.42 \\
1.39 \\
1.41\end{array}$ \\
\hline Mean & & 19.12 & 0.012 & 80.87 & 44.7 & 1.41 \\
\hline L.S.D 0.05 & & 0.95 & 0.001 & 12.95 & 5.64 & 0.02 \\
\hline Citrus & $\begin{array}{l}\text { B1 } \\
\text { B2 } \\
\text { B3 }\end{array}$ & $\begin{array}{l}19.00 \\
20.00 \\
19.50 \\
\end{array}$ & \begin{tabular}{|l|}
0.007 \\
0.008 \\
0.005 \\
\end{tabular} & $\begin{array}{l}81.00 \\
80.00 \\
80.50 \\
\end{array}$ & \begin{tabular}{|l}
48.10 \\
34.90 \\
34.90 \\
\end{tabular} & $\begin{array}{l}1.41 \\
1.40 \\
1.41 \\
\end{array}$ \\
\hline Mean & & 19.5 & 0.0066 & 80.50 & 39.30 & 1.406 \\
\hline L.S.D0.05 & & 0.92 & 0.002 & 0.92 & 3.14 & 0.01 \\
\hline Cotton & $\begin{array}{l}\text { C1 } \\
\text { C2 }\end{array}$ & $\begin{array}{l}19.00 \\
21.5\end{array}$ & \begin{tabular}{|l|}
0.007 \\
0.043 \\
\end{tabular} & $\begin{array}{l}81.00 \\
78.50\end{array}$ & \begin{tabular}{|l|}
48.10 \\
13.60
\end{tabular} & $\begin{array}{l}1.41 \\
1.39\end{array}$ \\
\hline Mean & & 20.25 & 0.025 & 79.75 & 30.85 & 1.40 \\
\hline T. test & & * & * & * & * & NS \\
\hline Egyptian stander & & $20 \%$ or less & - & - & & 1.42 or less \\
\hline Iraqian stander & & $21 \%$ or less & - & - & & 1.4 or less \\
\hline
\end{tabular}

EC.=Electrical conductivity ) (TSS= total soluble solid ) (V. = viscosity) (S.G. = Specific gravity)

Table 2: Some physical properties of Iraqian honeys.

\begin{tabular}{|c|c|c|c|c|c|c|}
\hline Honey type & Sample & $\begin{array}{c}\text { Moisture } \\
(\%)\end{array}$ & $\begin{array}{l}\text { EC. * } \\
\text { Ppm }\end{array}$ & \begin{tabular}{|c|} 
TSS $^{*}$ \\
$(\%)$
\end{tabular} & $\begin{array}{c}\text { V.* } \\
\text { (Poise) }\end{array}$ & S.G * \\
\hline Mountain honey & D1 & 16.5 & 0.010 & 83.5 & 87.5 & 1.42 \\
\hline Mountain honey & $\mathrm{D} 2$ & 16.5 & 0.006 & 83.5 & 87.5 & 1.42 \\
\hline Clover and Eucalyptus & D3 & 17.0 & 0.042 & 83.0 & 87.5 & 1.42 \\
\hline $\begin{array}{l}\text { Clover, Eucalyptus, Christs } \\
\text { thorn and Sun flower }\end{array}$ & D4 & 17.0 & 0.064 & 83.0 & 87.5 & 1.42 \\
\hline Citrus & D5 & 16.0 & 0.044 & 84.0 & 69.0 & 1.43 \\
\hline Clover, Eucalyptus and Coriander & D6 & 18.0 & 0.018 & 82.0 & 48.1 & 1.42 \\
\hline Clover and Eucalyptus & D7 & 17.5 & 0.021 & 82.05 & 69.0 & 1.42 \\
\hline Eucalyptus and Christs thorn & D8 & 19.0 & 0.039 & 81.0 & 48.1 & 1.41 \\
\hline Clover, Eucalyptus and Rosaceae & D9 & 19.0 & 0.009 & 81.0 & 48.1 & 1.41 \\
\hline Mean & & 17.4 & 0.028 & 82.5 & 70.3 & 1.42 \\
\hline L.S.D 0.05 & & 1.5 & 0.053 & 1.4 & 2.82 & NS \\
\hline Egyptian stander & & $\begin{array}{l}20 \% \text { or } \\
\text { less }\end{array}$ & - & - & - & $\begin{array}{c}1.42 \text { or } \\
\text { less }\end{array}$ \\
\hline Iraqian stander & & $\begin{array}{l}21 \% \text { or } \\
\text { less }\end{array}$ & - & - & - & $\begin{array}{c}1.42 \text { or } \\
\text { less }\end{array}$ \\
\hline
\end{tabular}


Table 3: Comparison between physical properties of Egyptian honeys.

\begin{tabular}{|c|c|c|c|c|c|}
\hline Honey types & Moisture & EC * & TSS * & V. * & S.G. * \\
\hline Clover & 19.12 & 0.012 & 80.87 & 44.70 & 1.41 \\
\hline Citrus & 19.50 & 0.0066 & 80.50 & 39.30 & 1.406 \\
\hline Cotton & 20.25 & 0.025 & 79.75 & 30.85 & 1.40 \\
\hline Mean & 19.62 & 0.0145 & 80.37 & 38.28 & 1.405 \\
\hline L.S.D.0.05 & 0.49 & 0.010 & 0.088 & 1.13 & NS \\
\hline Egyptian stander & $20 \%$ or less & - & - & & 1.42 or less \\
\hline Iraqian stander & $21 \%$ or less & - & - & & 1.42 or less \\
\hline
\end{tabular}

(EC.=Electrical conductivity) (TSS.= Total soluble solid) $(\mathrm{V} .($ poise $)=$ viscosity) (S.G=Specific gravity)

\section{Total soluble solids and Electrical Conductivity:}

The values of total soluble solids (TSS \%) in Egyptian and Iraqian honey standard. The highest TSS\% in Egyptian honeys was $82 \%$ (from clover honey A2) and in Iraqian honeys recorded $83 \%$ from citrus D5, while the lowest level of TSS \% in Egyptian honeys was $78.5 \%$ from cotton honey C2 and in Iraqian honeys recorded from two samples D8 and D9 .

Generally, results indicated that it not found significant differences between Egyptian and Iraqian honeys in relation to total soluble solids (TSS\%) (Table 4).

In relation to electrical conductivity (EC:ppm), the results indicated that degree of (EC) ranged in Egyptian honeys (clover between 0.008 to 0.019 ), (citrus between 0.005 to 0.008 ) and (cotton between 0.007 to 0.043 ), while in Iraqian honeys ranged between 0.006 to 0.064 .

Generally, it is cleared that low significant differences between Egyptian and Iraqian honeys in relation to Electrical conductivity (EC) (Table 4).

Table 4: Comparison between some physical properties of Egyptian and Iraqian honeys.

\begin{tabular}{|l|c|c|c|c|c|}
\hline Honey type & Moisture & $\begin{array}{c}\text { EC * } \\
\text { ppm }\end{array}$ & $\begin{array}{c}\text { TSS * } \\
\text { (\%) }\end{array}$ & $\begin{array}{c}\text { V. } \\
\text { (poise) }\end{array}$ & S.G. * $^{*}$ \\
\hline Egyptian honey & 19.5 & 0.013 & 80.5 & 39.82 & 1.41 \\
\hline Iraqian honey & 17.4 & 0.028 & 82.5 & 70.30 & 1.42 \\
\hline Mean & 18.45 & 0.02 & 81.5 & 55.06 & 1.415 \\
\hline T. test & NS & $*$ & NS & $*$ & NS \\
\hline Egyptian stander & $20 \%$ or less & - & - & - & 1.42 or less \\
\hline Iraqian stander & $21 \%$ or less & - & - & - & 1.42 or less \\
\hline
\end{tabular}

(EC.=Electrical conductivity) (TSS.= Total soluble solid) (V.(poise)= viscosity)

( $S . G=$ Specific gravity) 


\section{Viscosity and Specific gravity:.}

Viscosity values ranged between 13.60 to 69 poise in Egyptian honeys, while between 48.1 to 87.5 poise in Iraqian honeys. Therefor viscosity of Iraqian honeys was more than viscosity of Egyptian honeys (Table 1, 2).

The highest viscosity in Egyptian honeys was 69.00 poise (citrus A2) and in Iraqian honeys was 87.5 poise (D1, D2, D3 and D4), while the lowest viscosity was 13.60 in Egyptian honey (cotton $\mathrm{C} 2$ ) and 48.1 poise in Iraqian honeys (D6, D8 and D9).

Generally, results indicated that low significant differences between Egyptian and Iraqian honeys in relation to viscosity. In relation to specific gravity it was not clear differences between values of specific gravity in both Egyptian and Iraqian honey samples. The specific gravity ranged between 1.39 to 1.42 in Egyptian honeys, while between (1.41 to 1.43) (Tables 1, 2) and (Fig 9, 10). It not found significant differences between Egyptian honey (clover, citrus and cotton) and also between Iraqian honeys in all samples (Fig 2, 3).

These results indicated that not found in significant differences between Egyptian and Iraqian honeys (Table 4).

Finally, the results of some physical properties in Egyptian and Iraqian honeys indicated that it was need found significant differences between Egyptian and Iraqian honeys in relation to moisture, total soluble solids (TSS\%) and specific gravity, while it was found low significant differences in relation to electrical conductivity $(\mathrm{EC})$ and viscosity, these results may be due to Ecological factors in both country (Egypt and Iraq), such a temperature, relative humidity flora and geographic region and induction to quality of bee race type and beekeeping process. 
J. Plant Prot. and Path., Mansoura Univ., Vol. 6 (11), November, 2015

F1

1573 
Fathy, H.M. et al.

F2

1574 
J. Plant Prot. and Path., Mansoura Univ., Vol. 6 (11), November, 2015

F3

1575 


\section{REFERENCES}

A .O. A. C. (1995) Official methods of analysis. (16thed). Washington, DC:UAS:As. off. Ana. chem.

A. O. A. C. (1980) Official methods of analysis. Washington, DC: Ass off, Ana. Chem..

Codex Alimentarius Commission, CAC 1998. Codex Alimentarious Draft revised for honey. CAD CX P 5/102, Cl, 1998/12-S, FAO, Rome, Italy.

Codex Alimentarius Commission Standards, (1981/ revised 1987/ revised 2001) Codex Standards for honey, 1-7, FAO-Rome.

Crane, E. (1990). Bees and Beekeeping. Scientific, practice and World Resources. First ed., Heinemann Newnes, Halley Court, Jordan Hill, Oxford OX28EJ, London, UK.

El-Ansary, O. M. (2007) Bee in honey production and crop pollination. Monshaat El Maarif, Alexandria, Egypt (Arabic), 1458pp.

El-Metwally, A. E. (2015) Factors affecting the Physical and Chemical characteristics of Egyptian bee honey. PH. D. Thesis Fac. Agr. Cairo, Uni. Egypt, 333 pp.

Serrano, S.; Espejo, R. Villarejo, M.; Jodral, M. L., (2007). Diastase and invertase activities in Andalusian honeys. Int. J. Food Sci. Technol., 42: 76- 79.

Vorwhol, G. (1964) Dia messing der elektrischen heitfahigkeit des honig and die vermendung der messwerte zur sortendignose und zum Nachweis von vervals chungenmit zuckerfutterung shonig, Bienenforschung., 7: 37-47.

White, J. W.; Landis, W.D. (1980). Honey composition and properties. Beekeeping in the United states, Agriculture handbook number 335, revised October, pp: 82-91. 
"دراسات على بعض الخصائص الطبيعية للعسل المصري والعراقي"

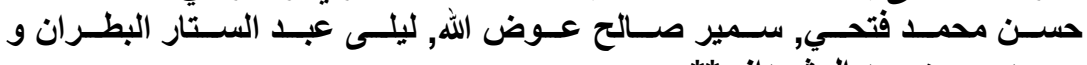

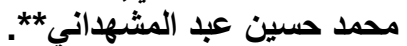
قسم الحشرات الأقتصادية, كلية الزراعة المثرة جامعة المنصورة.

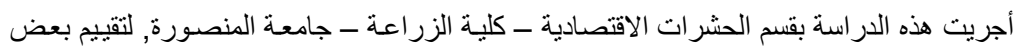

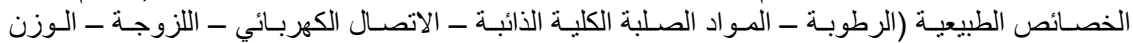

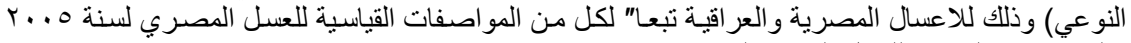

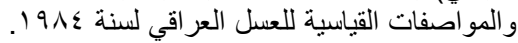

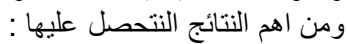

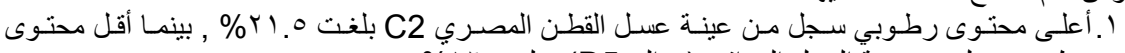

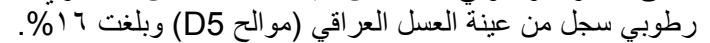

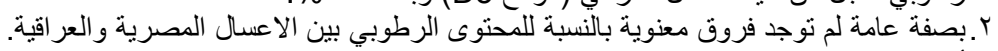

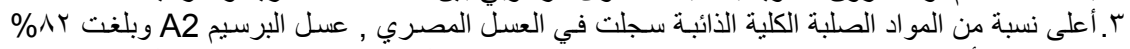

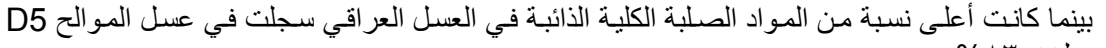

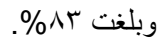
ع. بالنسبة للأتصال الكهربائي وجدت فروق معنوية منخفضـة بين الأعسال المصرية و العر اقية من حيث درجات الأتصال الكهربائي.

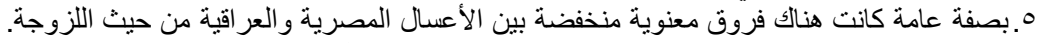

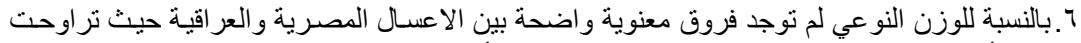

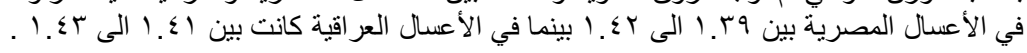

